\title{
KONTRIBUSI GRATITUDE DAN MEANING OF LIFE SEBAGAI UPAYA UNTUK MENGEMBANGKAN KESEHATAN MENTAL DI TEMPAT KERJA
}

\section{Indah Roziah Cholilah}

Dosen Fakultas Dakwah, Institut Agama Islam Negeri Jember Email: indah.rch260687@gmail.com

\begin{abstract}
Abstrak
Secara umum, kebersyukuran (gratitude) dan makna hidup(meaning of life) merupakan emosi positif yang ada dalam diri seseorang terkait dengan pemenuhan kebutuhan dan fungsi diri secara positif. Seseorang yang fokus pada rasa kebersyukuran dan kebermaknaan hidup, mampu membuat hidupnya menjadi lebih sejahtera, produktif dan memiliki kepuasan dan kebahagiaan dalam hidup, sehingga energi positif ini dapat menguatkan dan meningkatkan kesehatan mental seseorang, salah satunya saat ia berada ditempat kerja. Ketika membahas tentang produktivitas kerja, banyak sekali faktor penting yang secara langsung maupun tidak langsung mempengaruhi, salah satunya adalah kesehatan mental.Sehingga banyak sekali kajian-kajian pustaka dan hasil penelitian yang mengangkat fenomena kesehatan mental dari berbagai perspektif, baik persepektif fisik, sosial, emosional maupun mental.Kajian literature ini adalah untuk mengetahui bagaimana kontribusi kebersyukuran (gratitude) dan kebermaknaan hidup (meaningoflife) dapat menumbuhkan kesehatan mental pekerja di tempat kerja.
\end{abstract}

Kata kunci: Gratitude, Meaning Of Life, Kesehatan Mental

\section{Pendahuluan}

Diera globalisasi sekarang, telah banyak lembaga atau instansi mulai dari sektor pendidikan, kesehatan dan industri yang telah berdiri di Indonesia, dimana setiap lembaga pastinya sangat membutuhkan SDM yang dapat menjalankan setiap bisnis maupun kegiatan yang telah dirancang oleh lembaga tersebut. Agar visi dan misi dari lembaga bisa dicapai sesuai dengan harapan yang diinginkan, maka penting bagi lembaga memiliki SDM yang produktif, berinovasi, berfikir dan bertindak positif, serta memiliki banyak potensi lainnya yang dapat membantu perusahaan mencapai target yang ditetapkan. Untuk meningkatkan performasi kerja dan sikap produktifitas, maka faktor yang berperan penting untuk memunculkan sikap positif tersebut adalah, pekerjapekerja yang sehat secara fisik dan mental.Namun dalam kajian kali ini, penulis ingin fokus terhadap pekerja. Mereka yang sehat secara mental akan dapat menumbuhkan semangat kerja yang baik. Seperti, pada hasil penelitian 
sebelumnya yang dilakukan oleh koopman, dkk (2002) menemukan bahwa produktivitas kerja, dipengaruhi oleh kesehatan mental para pekerja.Dalam penelitiannya tersebut, Koopman, dkk.(2002) menemukan adanya hubungan yang sangat erat antara kedua varibel tersebut, hal ini menunjukkan bahwa kesehatan mental mempunyai peran yang sangat penting dan strategis dalam menciptakan budaya organisasi yang efektif dan efisien.Maka dari itu, perlu dibangun sebuah sistem ditempat kerja, supaya dapat fokus pada hal-hal yang bisa resiliansi terhadap stress ditempat kerja.

Kesehatan mental sama pentingnya dengan kesehatan fisik, yang keduanya sama-sama harus dijaga. Namun sayangnya, banyak orang lebih cepat menyadari kondisi fisik yang sakit, dari pada mental yang sebenarnya juga rentan mengalami gangguan. Meski cenderung memiliki bentuk dan fungsi yang sama, namun setiap orang memiliki kesehatan mental yang berbeda, hal tersebut terjadi, lantara andanya perbedaan lingkungan dan cara dalam menghadapi permasalahan yang berbeda bagi setiap individu. Individu yang bekerja dalam satu kantor pun akan memiliki kondisi kesehatan mental yang berbada. Jabatan yang tinggi ataupun lingkungan kerja yang nyaman tidak menjadi jaminan seseorang terhindar dari masalah kesehatan mental.Kesehatan mental saat ini menjadi sebuah isu yang sangat penting untuk dibahas terutama kesehatan mental dalam dunia kerja. Danna dan Griffin (1999) misalnya, yang menyatakan bahwa alasan penting kesehatan mental ditempat kerja, yaitu: pertama, pengalaman individu baik secara fisik, emosional, mental atau sosial akan mempengaruhi bagaiamana seseorang akan bersikap ditempat kerja. Kedua, kesehatan mental pekerja menjadi isu penting karena akan menumbuhkan kesadaran terhadap faktor-faktor lain yang menimbulkan resiko bagi pekerja. Misalkan, karakteristik tempat kerja yang mendukung keamanan dan kesejahteraan bagi pekerja, potensi ancaman kekerasan dan agresi ditempat kerja, bahkan hubungan relasi antara pimpinan dan bawahan yang berimplikas pada kesehatan mental keduanya.Ketiga, kesehatan mental menjadi bagian penting karena kesehatan yang rendah akan mempengaruhi kinerja individu yang bekerja. Namun secara umum, kebijakan yang berfokus kesana masih memelurkan advokasi terus menerus karena 
berbagai tantangan praktis ditempat kerja membuat implementasinya tidak selalu menjadi prioritas. Di Negara maju seperti Bratania Raya, sikap terhadap pekerja yang mengalami masalah kesehatan mental jiwa sudah meningkat tapi tetap perlu advokasi untuk memformalkan sikap tersebut menjadi kebijakan perusahaan (Little, Henderson, Brohan \& thornicroft, 2011).

Menurut World Healt Organization (2012), terdapat 450 juta jiwa didunia mengalami gangguan mental dan sepertiganya tinggal di Negara berkembang. Pravelensi indvidu hidup dengan depresi sekitar 300 juta jiwa dalam waktu 10 tahun, dan masih terus mengalami peningkatan sampai sementara, 23 juta jiwa mengalami gangguan jiwa berat dan 800 ribu kematian terjadi diseluruh dunia akibat bunuh diri (Gerintya, 2017). WHO mengemukakan bahwa Negara bagian Asia merupakan Negara dengan tingkat gangguan mental paling tinggi di dunia, hal ini dikarenakan kurangnya jumlah tenaga medis kesehatan jiwa dan menjadi Asia sebagai benua dengan beban gangguan mental tertinggi di dunia. Dilansir dari The Corversation, para pekerja di Inggris mengalami krisis kesehatan mental, sekitar 4,6 juta pekerja dari 7\% populasi pekerja di Inggris mengalami depresi. Total $25 \%$ dari seluruh populasi di Uni Eropa diinformasikan akan segera melaporkan gangguan kesehatan mental yang tejradi di beberapa titik kehidupan mereka. Pekerja yang didiagnosis mengalami gangguan kesehatan mental menunjukkan beberap gejala seperti mengalami kesulitan berkonsentrasi, gangguan ingatan, sulit untuk membuat keputusan, hingga kehilangan minat dalam bekerja, performa kerja menjadi memburuk tidak produktif (Ecka Pramita, Majalah Kartini.co.id). Hasil penelitian lainnya, juga menjelaskan bahwa usia kerja dibeberapa Negara maju, seperti Australia dan Amerika menunjukkan saat ini diperikatan satu dari enam usia kerja mengalami kondisi mental yang bermasalah (Harvey, 2014). Kondisi mental yang bermasalah ini ditengarai telah menjadi penyebab tingginya angka ketikdakhadiran (absence) dan ketidakmampuan (incapability) kerja yang menjadi penyebab rendahnya performan dan produktivitas di tempat kerja.Penelitian lainnya, yang memperkuat penelitian diatas adalah, mereka para kelompok kerja yang bergerak dibidang sosial, seperti perawat kesehatan, pendidikan, kepolisian, keagamaan dan lain sebagainya, sering 
terindetifikasi sebagai pekerja yang cenderung mengalami kejenuhan kerja (burnout) (Dafiddoff, 1991). Kejenuhan kerja ini merupakan akibat stress kerja dan beban keja yang paling umum, gejalanya adalah rasa bosan, depresi, pesimisme, kurangnya berkonsentrasi, kualitas kerja memburuk, ketidakpuasan, keabsenan, dan seringnya mengalami sakit secara fisik. Pada para pekerja berjenis kelamin perempuan, misalnya dimana konflik peran seringkali dirasakan, ini disebabkan karena perempuan yang berkarir dan menjadi ibu rumah tangga, seringkali dihadapkan oleh konflik yang akan memperburuk kesehatan mentalnya, disfungsi keluarga, kelelahan dan menurunnya kesejahteraan hubungan suami-istri. Menurut Apollo dan Andi (2012) mengungkapkan bahwa ketidakbahagiaan wanita karir disebabkan oleh adanya rasa tertekan, kurangnya dukungan suami, konflik kehadiran anak, tingginya tuntutan dan masalah pekerjaan, hubungan antar anggota keluarga yang kurang harmonis, tingginya kebutuhan finansial dan tidak tercapainya aktualisasi diri.

Beberapa ahli berpendapat bahwa banyak sekali faktor ynag mempengaruhi kesehatan mental ditempat kerja, salah satunya adalah emosi dan sikap yang positif.Bersyukur dan pemaknaan hidup yang positif, memberikan kontribusi yang cukup besar untuk mengembangkan kesehatan mental terutama ditempat kerja.Pribadi yang sehat secara mental, ia biasanya memiliki keseimbangan yang baik dalam aspek psikologis dan sosial lingkungannya, sehingga ia mampu mencapai kesejahteraan hidup, kebahagiaan dan dapat menjalankan fungsinya sebagai organisme. Ketika mereka sejahtera dan bahagia dengan apapun yang dilakukan, ia mampu menggerakan dan menginventasikan sumber daya yang dimiliki demi membangun sesuatu yang lebih baik, yang akan bernilai dimasa depan.

Maka dari itu, tujuan dari penulisan artikel ini bertujuan untuk melihat seberapa besar kontribusi antara kebersyukuran dan kebermaknaan hidup dalam mengembangkan kesehatan mental ditempat kerja.dan sebagai referensi bagi peneliti untuk ditindaklanjuti dalam kegiatan penelitian untuk diuji kebenarannya. 


\section{Tinjauan Teori}

\section{Gratitude}

Bersyukur (gratitude)sebagai emosi positif yang menimbulkan perasaan yang menyenangkan dan khas, yang berwujud rasa syukur atau rasa terimakasih, yang muncul ketika kita menerima kebaikan (kindness, compassion, love), manfaat (benefit), atau bantuan altruistik dari pihak lain (Emmos, R.A., \& McCullough, M. E 2003). Selain itu, sikap bersyukur juga salah satu kondisi psikologis sebagai sebuah emosi, sikap, kebijakan moral dan sifat keperibadian sebagai salah satu cara yang dapat memberikan kontribusi terhadap kesehatan mental ( McCullough, Emmos, Tsang, 2002). Bersyukur adalah sikap batin (state of mind, state of heart) yang memiliki efek sangat membebaskan, dan merupakan emosi positif yang sangat kuat.McCullough, Emmons, \& Tsang (2002) membagi gratitude menjadi tiga tingkatan, yaitu gratitude sebagai trait, mood dan sebagai emosi.

Gratitude sebagai trait merupakan sebuah kecenderungan stabil terhadap beberap respon emosional yang menentukan ambang batas individu untuk merasakan keadaan emosional tertentu (Iman, 2016).Orang yang memiliki gratitude sebagai traiit yang tinggi, lebih bahagia dalam menjalani kehidupannya, serta memiliki harapan yang lebih tinggi didalamnya hidupnya. Sebaliknya, orang yang memiliki gratitude sebagai trait yang rendah, akan lebih cenderung untuk mengalami depresi, memeliki kebencian, dan sifat iri hati terhadap orang lain (McCullough, Emmons, \& Tsang, 2004)

Individu yang mengalami emosi dari gratitude biasanya disertai dengan ekspresi dan tindakan yang terlihat jelas, sedangkan pada individu yang mengalami gratitude sebagai suasana hati hal ini tidak akan terlihat jelas. Suasana hati dapat mempengaruhi kemampuan seseorang untuk memproses informasi, reaksi fisiologis, dan fenomena psikologis lainnya. Suasana hati juga akan mempengaruhi kognitif seseorang. Oleh karena itu, seseorang yang sering kali mengalami gratitude sebagai suasana hati, akan cenderung memiliki tingkat stress yang lebih rendah (Wood, Joseph, \& Linley, 2007). Sedangkan seseorang mengalami emosi dari gratitude, orang tersebut akan memiliki kecenderungan 
untuk melakukan tindakan tertentu yang dapat berkontribusi pada kebahagiaan dan kesejahteraan hidup.

Imam Abu Hamid Muhammad Al-Ghazali dalam karangan fenomenalnya, Ihya' Ulumuddin mengemukakan bahwa syukur diimbangi dengan memanfaatkan anugrah yang sudah Allah SWT berikan demi terlaksananya amar ma'rufnahimunkar (Yasin, 2010). Syukur menjadi salah satu konsep yang mempunyai kedudukan penting dalam agama islam. Dalam firman-Nya konsep syukur kerap kali digandenykan dengan konsep-konsep lain seperti halnya iman dan perintah dzikir, sebagaimana yang dijelaskan dalam firman-Nya: "Mengapa Allah akan menyiksamu, jika kamu bersyukur dan beriman? Dan Allah adalah Maha Mensyukuti lagi Maha Mengetahui". (an-Nisa':4:147). Dalam Al-Qur'an surat An-Nahl ayat 78 berbunyi“Dan Allah mengeluarkan kamu dari perut ibumu dalam keadaan tidak mengetahui sesuatupun, dan Dia memberi pendengaran, penglihatan, dan hati, agar kamu bersyukur. Dalam ayat lainnya juga dijelaskan bahwa "Dan (ingatlah juga) tatkala Tuhan-mu memaklumkan: "Sesungguhnya, jika kamu bersyukur, pasti kami akan menambah (nikmat) kepadamu dan jika kamu mengingkari (nikmat-Ku) maka sesungguhnya azab-Ku sangat pedih (QS. Ibrahim, ayat 7).

Kata syukur diambil dari bahasa Arab yaitu syakara, syukuran.Syukur juga berarti menampakkan sesuatu kepermukaan.Dalam hal ini menampakkan nikmat yang telah Allah beri.Sedangkan menurut istilah syara', syukur adalah pengakuan terhadap nikmatyang dikaruniakan Allah yang disertai dengan kedudukan kepadaNya dan mempergunakan nikmat tersebut sesuai dengan tuntutan dan kehendak Allah (Mahfud, 2014).Syukur seringkali dipraktekkan dengan pengucapakan "Alhamdulillah". Kata ini sebagai symbol dari rasa kebersyukuran. Akan tetapi, syukur yang sesungguhnya adalah tidak hanyacukup pada pengucapan dengan lisan, namun juga berkaitan dengan hati dan anggota badan lainnya.Seseorang yang mengaku bahwa ia bersyukur, namun tidak bergerak dan tidak bertindak melakukan kebaikan, bisa jadi rasa syukurnya semua atau dangkal.

Ketika suatu dorongan yang dibangkitkan gratitude untuk berterima kasih dan berbuat baik diikuti dan dilaksanakan, maka akan memiliki kekuatan 
transformatis yang besar. Gratitude yang telah menetap menjadi bagian dari jati diri pribadi, biasanya akan menjadi kekuatan moral yang dapat menggerakkan si pribadi mengarahkan hidupnya untuk memberikan kontribusi yang khas dari dirinya. Individu yang mampu merasakan gratitude sudah menjadi bagian dari dirinya, mereka disebut sebagai orang-orang dengan gratefulpersonality, dimana setiap segala sesuatunya dilihat dari kacamata gratitude, sehingga mereka dapat mensyukuri segala sesuatu, hal yang baik, juga hal yang tidak baik disaat senang maupun disaat susah.

Beberapa hasil penelitian tentang pribadi yang mudah bersyukur (gratefulpersonality): gratitude berkorelasi positif engan sifat agreeableness (cenderung akomodatif terhadap orang lain) dan berkorelasi negatif dengan sifat openness atau cenderung berpikiran terbuka (Saucaier \& Goldberg, 1998). Menurut Robert A. Emmons (Emmons, R.A \& Shelton, C.M, 2002, Emmons, 2004) seorang professor dan pakar peneliti tentang gratitude dari University of California, gratitude terbukti secara ilmia memiliki efek-efek yang sangat positif, baik untuk kesehatan mental, kesehatan fisik, maupun relasi sosial. Selain itu, penelitian lainnya mengenai kebersyukuran pada orang tua $A B K$, dimana mereka lebih mudah menerima (tawakkal) semua takdir atau ketetapan yang telah Allah rencanakan dengan baik, orang tua ABK juga lebih memiliki rasa cintah dan kasih sayang yang tinggi kepada anak, kecenderungan ingin bertindak positif dengan cara membantu orang lain yang memiliki permasalahan yang sama, merasakan ketenangan jiiwa/kepuasan batin, optimism serta harapan yang besar dalam memandang hidup (Hambali, dkk, 2015). Sesungguhnya dimensi-dimensi kebersyukuran ini, sifatnya komprehensi, meliputi seluruh dimensi-dimensi yang telah dikemukakan baik dalam pandangan barat maupun dalam pandangan islam. Dalam hal ini kebersyukuran diapresiasikan baik pada diri sendiri, pada orang lain dan kepada Allah sebagai sang khalik.

\section{The Meaning of Life (Makna Hidup)}

Schultz (1991) mengartikan makna hidup sebagai pemberian kualitas kehidupan pada diri pribadi dalam rangka pemenuhan diri. Pendapat tersebut 
menunjukkan bahwa kebermaknaan hidu akan melahirkan nilai-nilai diri individu, sehingga dirinya akan merasakan keberhargaan diri yang selanjutnya akan menampilkan aktivitas yang seiring dengan tujuan hidupnya. Kebermaknaan hidu menurutu Frankl (2004) dapat diwujudkan dalam sebuah keinginan menjadi orang yang berguna bagi orang lain, baik bagi keluarga, teman, komunitas Negara, bahkan umat manusia. Makna hidup (TheMeaning of Life) adalah hal-hal yang dianggap sangat penting dan berharga serta dapat memberikan nilai khusu bagis seseorang, sehingga layak dijadikan tujuan dalam kehidupan (the purpose in life)(Bastaman, 2007).Bila hal itu berhasil dipenuhi akan menyebabkan seseorang merasakan kehidupan yang berarti dan pada akhirnya akan menimbulkan perasaan bahagia (happiness).

\section{Sumber-Sumber Makna Hidup}

Makna hidup tidak saja dapat ditemukan dalam keadaan-keadaan yang menyenangkan, tetapi juga dapat ditemukan dalam penderitaan sekalipun, selama kita mampu melihat hikmah-hikmahnya. Tanpa bermaksud menentukan apa yang seharusnya menjadi tujuan da makna hidu seseorang, dalam kehidupan ini terdapat tiga bidang kegiatan yang secara potensial mengandung nilai-nilai (value) yang memungkinkan seseorang menemukan makna hidup. Diantaranya adalah:

1. Creative values (nilai-nilai kreatif): kegiatan berkarya, bekerja, mencipta serta melaksanakan tugas dan kewajibab sebaik-baiknya dengan penuh tanggung jawab.

2. Experietial values (nilai-nilai penghayatan), yaitu keyakinan dan penghayatan akan nilai-nilai kebermaknaan, kebajikan, keindahan, keimanan, dan keagamaan, serta cinta kasih. Menghayati dan menyakini suatu nilai dapat menjadikan seseorang berarti hidupnya.

3. Attitudinal values (nilai-nilai bersikap), yaitu menerima dengan penuh ketabahan, kesabaran, dan keberanian segala bentuk penderitaan yang tidak mungkin dielakkan lagi, setelah segala upaya dan ikhtiar dilakukan secara maksimal. 
Frankl (2004) menjelaskan bahwa ada beberapa faktor yang mempengaruhi kebermaknaan hidup, yaitu: loneliness, kebutuhan, agresivitas, pemahaman diri, ketahanan diri, self commitment, pengambilan keputusan, empati, interaksi sosial, sikap positif, well being, kebersyukuran, frustasi eksistensi dan neurosis noogenik. Bastaman (2007) juga menjelaskan 5 metode yang dapat membantu individu untuk menemukan dan menetapkan makna dan tujuan hidup yang jelas, yaitu: a). Pemahaman Diri: mengenali secara obyektif kekuatan-kekuatan dan kelemahan diri sendiri baik yang merupakan potensi maupun yang suduah teraktualisasi, kemudian kekuatan-kekuatan tersebut dikembangkan dan ditingkatkan, serta kelemahan-kelemahan di hambat dan dikurangi. b). Bertindak Positif: mencoba menerapkan dan melaksanakan hal-hal yang dinggap baik dan bermanfaat dalam perilaki da tindakan nyata sehari-hari. c). Pengakraban Hubungan: meningkatkan hubungan baik dengan pribadi-pribadi tertentu, seperti: keluarga, teman dan rekan kerja sehingga masing-masing saling mempercayai, saling memerlukan dan saling membantu satu sama lain. d). Pendalaman Catur Nilai: berusaha untuk memahami dan memenuhi empat macam nilai yang merupakan sumber makna hidup, yaitu nilai kreatif (kerja, karya, cipta); nilai penghayatan (kebenaran, keindahan, kasih, iman); nilai bersikap (menerima dan mengambil sikap yang tepat terhadap derita yang tidak dapat dihindari lagi); nilai pengharapan (percaya adanya perubahan yang lebih baik dimasa yang akan datang). e). Ibadah: berusaha memahami dan melaksanakan hal-hal yang diperintahkan Tuhan dan mencegah diri dari apa yang dilarang-Nya. Ibadah yang khusyuk sering mendatangkan perasaan tentram dan tabah, serta menimbulkan perasaan mantap seakan-akan mendapat bimbingan dan petunjuk-Nya dalam menghadapi berbagai masalah hidupnya.

Menurut Frankl (2004) ciri-ciri orang yang merasakan hidup bermakna: a). menjalin hidup sehari-hari dengan semangat dan penuh gairah serta jauh dari perasaan hampa. b). tugas-tugas dan pekerjaan sehari-hari merupakan sumber kepuasan dan kesenangan tersendiri, sehingga dalam pengerjaannya semangat dan penuh tanggung jawab. c). mampu menyesuaikan diri dengan lingkungan, artinya menyadari pembatasan-pembatasan lingkungan, tetapi 
dalam keterbatasan itu tetap menentukan sendiri apa yang palibg baik untuk dilakukan. d). menyadari makna hidup dapat ditemukan dalam kehidupan meski tergolong buruk, dan dapat menghadapi dengan tabah dan menyadari bahwa hikmah selal ada dibalik penderitaan. e). kemampuan untuk menentukan tujuan-tujuan pribadi dan menentukan makna hidup sebagai sesuatu yang sangat berharga dan sangat tinggi nilainya. f). mampu mencitai dan menerima kasih sayang orang lain dan menyadari bahwa cinta kasih merupakan salah satu nilai yang menjadikan hidup lebih indah. Menurut Bastaman (2007) ciri-ciri orang yang merasa tidak memiliki hidup yang bermakna, adalah sebagai berikut: a). individu merasa hampa dan gersang. b). individu merasa tidak memiliki tujuan hidup. c). merasa hidup tidak berarti. d). Bosan dan apatis.

\section{Kontribusi Gratitude dan Meaning Of Life Sebagai Upaya Untuk}

\section{Mengembangkan Kesehatan Mental di Tempat Kerja.}

Dunia berkembang begitu pesatnya didalam berbagai bidang kehidupan.Begitupun dalam dunia industry dan sektor usaha yang berkembang berkat penggunaan ilmu pengetahuan dan tekhnologi. Disamping itu, kompleksnya masyarakat modern dan masalah-masalah manusia dalam system ekonomi dan produksi juga semakin besar, sehingga tidak jarang perkembangan dan kompleksitas masyarakat modern ini memberikan dampak yang besar terhadap kehidupan sosial dan mental yang dimiliki. Mereka yang menjalani kegiatan industry dan organisasi, tidak jarang mengalami stress kerja, sehingga produktivitas kerja menjadi menurun. Hal ini bisa diakibatkan karena beban kerja yang berlebihan, tekanan atau desakan waktu, kualitas penyelia yang jelek, iklim politik yang tidak aman, wewenang yang tidak memadai untuk melaksanakan tanggung jawab, hubungan interpersonal dengan rekan kerja dan stakeholder, konflik, frustasi dan masih banyak kesenjangan lainnya yang terjadi. Permasalahan-permasalahan tersebut jika tidak bisa disikapi dengan tepat dan benar maka akan mempengaruhi pribadi dan hubungan sosial individu. Maka perlu bagi individu-individu yang bekerja, untuk melatih ketahanan diri serta mengembangkan sikap, fikiran dan 
emosi yang positif untuk menghadapi berbagai macam persoalan hidup yang semakin kompleks.Sikap dan emosi positif tersebut bisa dengan menunjukkan kebersyukuran dalam merespon suatu situasi pada kehidupan sehari-hari, terutama kehidupan ditempat kerja.Kebersyukuran merupakan salah satu pembahasan yang dikaji dalam konsep positivepsychology yang sedang berkembang saat ini.Banyak tokoh dari barat yang berusaha mengungkap makna dari konsep tersebut.Sehingga hal ini sangat menarik bagi mereka, untuk memberikan kontribusi penting dalam membantu menyelesaikan permasalahan masyarakat sehingga dapat merasakan kualitas hidup secara utuh. Sebenarnya, konsep bersyukur telah lebih dulu dibahas oleh cendikia muslim, salah satunya adalah imam Al-Ghazali. Imam Abu Hamid Al-Ghazali mendefinisikan konsep syukurt mencakup 3 kompenen.Pertama, ilmu dengan mengetahui kenikmatan yang diperoleh berasal dari Allah SWT beserta perantaranya.Kedua, keadaan dengan kesenangan atas nikmat yang diperoleh yang nantinya mengantarkan untuk semakin dekat dengan-Nya. Ketiga, amal dengan menggunakan kenikmatan tersebut dalam jalan yang diridhoi Allah SWT (Lutfia, 2016). Istilah syukur (gratitude) kerap kali dijustifikasi dalam pembenaran tindakan menerima apa adanya, degan tanpa usaha untuk melakukan kreativitas, inovasi, dan improfisasi, bahkan terkadang dimaknai untuk menghentikan tindakan dalam peningkatan kualitas pribadi. Syukur pun seringkali hanya diucapkan oleh lisan namun tidak ada tindakan positif yang bisa dilakukan, sehingga kurangnya penghayatan individu terhadap konsep syukur yang sebenarnya.Syukur (gratitude) bukan pula diartikan ketika hanya mendapatkan kesenangan atau harapan telah tercapai, karena sesuatu yang menyenangkan dan pemberian yang diterima tidak semuanya membangkitkan gratitude.Ada pemberian yang rasanya impas saja, karena hal itu adalah hak yang harus diterima setelah seseorang bekerja keras melakukan kewajibannya, sehingga kesenangan yang timbul terasa biasa saja, seperti besarnya kompensasi yang diterima.

Dalam konteks ini, kebersyukuran kerja diartikan dengan bagaimana karyawan mampu mensyukuri apapun terkait tugas dan tanggung jawab yang diterima. Seseorang yang bersyukur akan lebih mungkin memperhatikan 
manfaat dan aspek yang menyenangkan, meski berbagai tekanan datang berlarut-larut karena tuntutan kerja dan persaingan yang keras. Pengakuan manfaat atas apa yang diperoleh serta menitikberatkan pada aspek positif pekerjaan dari pada negatifnya memungkinkan dapat menumbuhkan perasaan lebih dalam menikmati pekerjaan, dan hal ini akan meminimalisir stress kerja yang bisa mempengaruhi kondisi emosional, proses berfikir dan kondisi fisik karyawan.

Selaras dengan hasil penelitian sebelumnya yang dilakukan oleh Robert A. Emmos, dkk, banyak manfaat yang bisa diperoleh bagi mereka yang mampu bersyukur dalam menghadapi banyak situasi baik yang menyenangkan dan tidak menyenangkan, diantaranya: pertama, manfaat fisik; memiliki kekebalan tubuh yang lebih kuat, lebih dapat menahan rasa sakit, tekanan darah lebih rendah, lebih sering berolahraga, lebih merawat kesehatan, tidur lebih lama dan segar sesudahnya. Kedua, manfaat psikologis; lebih tinggi tingkat emosi positifnya, lebih siaga, lebih bersemangat, lebih bersukacita dan gembira, lebih optimis dan lebih bahagia.Ketiga, manfaat sosial; lebih suka menolong, murah hati, berbelas kasih, mudah memafaatkan, lebih ramah dan mudah bersosialisasi, lebih sedikit merasa kesepian dan terisolasi (Iman, 2018).Masih banyak lagi manfaat yang ditimbulkan jika seseorang dapat menikmati kehidupan saat ini baik mereka yang menerima nikmat suka maupun duka, seperti pelipatgandaan dan penyebarluasan kebaikan, pembentukan ikatan persodaraan, dan penguatan komunitas.

Individu yang mampu mensyukuri apapun yang dimilikinya, serta berusaha untuk memberikan dedikasi yang terbaik untuk perusahaan tempatnya bekerja, cenderung hatinya tentram dan bahagia, sehingga mereka mudah menangkal berbagai macam kekecewaaan dan kepahitan. Efek emosi positif yang kuat tersebut, dapat membangkitkan kesehatan baik secara fisik maupun mental.Bersyukur juga dapat menunjang rasa kebermaknaan hidup (meaningoflife) dan penghargaan diri (self esteem), karena individu akan menyadari bahwasanya kehidupannya sangatlah berharga dan berarti, sehingga ia fokus untuk mencapai tujuan hidup yang bahagia, bisa berguna 
untuk orang lain, bermartabat bagi dirinya sendiri, keluarga, lingkungan kerja, maryarakat sekitar dan di mata Allah SWT.

Keinginan untuk hidup bermakna memang benar-benar merupakan motivasi utama pada manusia.Hasrat inilah yang mendorong setiap orang melakukan berbagai kegiatan seperti, bekerja, berkarya, berimprovisasi setiap kemampuan yang dimiliki.Menurut Frankl sumber utama dari motivasi adakah kebermaknaan hidup (meaning of life) (Bastaman, 2007). Kebermaknaan hidup dapat diwujudkan dalam sebuah keinginan menjadi orang yang berguna bagi orang lain. Kehidupan yang sehat adalah kehidupan yang penuh makna.Makna hidup ini juga bermula dari sebuah visi kehidupan, harapan dalam hidup, dan adanya alasan kenapa seseorang harus terus hidup. Dengan visi tersebut seseorang akan menjadi tangguh dalam menghadapi kesulitan hidup seberat apapun. Bagi mereka yang bekerja, pekerjaan yang ditekuni hanyalah merupakan sarana yang memberikan kesempatan untuk menemukan dan mengembangkan makna hidup. Makna hidup tidak terletak pada sulit dan mudahnya pekerjaan yang diemban, namun lebih bergantung pada pribadi yang bersangkutan dalam memandang semua pekerjaan tersebut menjadi positif dan mencitai pekerjaan itu serta cara bekerja yang mencerminkan keterlibatan pribadi pada pekerjaannya. Makna hidup dapat dicapai daricreative values, experiential value, attitudinal values. Creative values (nilai kreatif) mengilhami inividu untuk menghasilkan, menciptakan, dan mencapai sukses dalam suatu pekerjaan. Individu yang memiliki nilai-nilai kreativitas, mereka akan senantiasa menekuni suatu pekerjaan dan melibatkan seluruh pribadinya terhadap tugas dengan berusaha untuk mengerhakan tugas tersebut sebaikbaiknya. Melalui karya da kerja, seseorang dapat menemukan arti hidup dan menghayati kehidupannya dengan penuh makna. Bekerja dapat menimbulkan makna dalam hidup, secara nyata jika seseorang yang telah lama tidak berhasil mendapatkan pekerjaan, lalu kemudian mendapatkan tawaran bekerja dengan pendapatkan yang tidak terlalu besar, sehingga kemungkinan besar ia akan menerima tawaran tersebut karena ia merasa berarti dengan memiliki suatu pekerjaan dari pada tidak sama sekali. Experiential value (nilai penghayatan)mencakup keyakinan dan penghayatan akan nilai-nilai 
kebenaran, kebajikan, keindahan, keimanan, keagamaan, serta cinta kasih. Tidak sedikit orang yang menghabiskan waktunya untuk menekuni satu bidang pekerjaan yang tertentu, dimana dengan mereka bekerja mereka mendapatkan kehidupan yang bermakna, mereka juga merasa bahwa dirinya sangat berarti karena perusahaannya sangatlah membutuhkan dirinya. Terutama kepada mereka yang memiliki cinta dan kasih, akan senantiasa menunjukkan kesediaan untuk menampilkan sikap kerja yang terbaik sehingga membuat orang lain disekitarnya bahagia Attitudevalues(nilai bersikap) membawa seseorang kepada pilihan bersikap terhadap kondisi negative yang tidak dapat dihindari, misalnya dalam kondisi menghadapi pekerjaan yang menekan, stress kerja, kematian, sakit yang sulit disembuhkan setelah upaya dan ikhtiar dilakukan. Pada attitudevalues, yang diubah bukan keadaannya, melainkan sikap yang diambil dalam menghadapi keadaan itu. Keadaan mendesak secara kuat mempengaruhi dalam mencapai makna hidup, sebagian besar bergantung pada sikap individu terhadap keadaan mereka. Jika individu tidak mengejar makna hidupnya, maka dia akan mengalami vacuumexistential atau meaninglessness. Hal ini sering diiringi dengan perasaan kebosanan, kejenuhan, stress, ketidakpedulian, perasaan tidak bermakna dan ketidakpuasan terhadap hidup.Cobaan atau masalah yang dihadapi memang dapat memberikan makna apabila seseorang dapat mengubah sikapnya terhadap masalah tersebut menjadi lebih baik.

\section{Kesimpulan}

Mereka yang mampu bersyukur terhadap situasi yang dihadapi maka mampu menjalankan tugas dan tanggung jawab kendati terbilang cukup berat.Meski terkadang tuntutan kerja datang secara terus menerus karena persaingan yang keras, namun seseorang yang bersyukur melihat semuanya dengan sudut pandang yang positif.Sehingga padangan positif terkait permasalahan yang dihadapi, masih tetap memungkinkan individu dapat menumbuhkan perasaan yang lebih dalam menikmati pekerjaan.Selain itu, individu yang mampu melihat kehidupannya lebih bermakna, mereka biasanya dapat terus mengembangkan kreatifitas, mampu menghayati setiap kondisi 
yang dijalani, dan mampu bersikap lebih bijakasana, sabar dan tabah dalam menghadapi setiap persoalan.Sikap, fikiran dan emosi positif ini mampu meminamlisir stress, jenuh, dan rasa bosan yang seringkali terjadi ditempat kerja yang disebabkan karena beban tugas yang besar. Sehingga dengan bersyukur seseorang dapat menjalankan seluruh aktifitasnya dengan bermakna, dan mereka yang benar-benar merasakan bahwa kehidupannya bermakna kemungkinan besar akan merasakan kebahagiaan. Mereka yang bahagia akan mampu menumbuhkan semangat dalam bekerja, dan kebahagiaan itu menjadi salah satu indikasi bahwa individu sehat secara mental.

\section{Daftar Pustaka}

Apollo.,\& Andi, C. (2012). Konflik Peran Ganda Perempuan Menikah yang Bekerja Ditinjau dari Dukungan Sosial Keluarga dan Penyesuaian Diri.Tesis.Universitas Katolik Widya Mandala Madiun.

Arif, S (2016). Psikologi Positif: Pendekatan Saintifik Menuju Kebahagiaan. Jakarta: PT. Gramedia Pustaka Utama.

Bastaman, H.D. (2007). Logoterapi: Psikologi untuk Menemukan Makna Hidup dan Meraih Hidup Bermakna. P.T. Raja Grafindo Persada, Jakarta.

Danna, K., \& Griffin, R. W. (1999).Health and well-being in the workplace: A review and synthesis of the literature. Journal of Management, 25(3), 357-384.

Davidoff, Linda L, (1991).Psikologi Suatu Pengantar, Jakarta: Erlangga.

Emmons, R. A., \& McCullough, M. E. (2003).Counting Blessings Versus Burdens: An Experimental Investigation of Gratitude And Subjective Well-Being in Daily Life. Journal of Personality and Social Psychology, 84(2), 377.

Gerintya, S. (2017).Statistik Bunuh Diri dan Darurat Kesehatan Mental.Diunduh dari tirto.id: wwww.tirto.id. Diakses pada tanggal 25 September 2018.

Hambali, Meiza, \& Fahmi.(2015). Faktor-Faktor Yang Berperan Dalam Kebersyukuran (Gratitude) Pada Orang Tua Anak Berkebutuhan Khusus Perspektif Psikologi Islam. Sympathic, Jurnal Ilmiah Psikologi, Vol. 2., Hal. 94 - 101 
Harvey, S.B., Joyce, S., Tan, L., Johnson, A., Nguyen, H., Modini, M., \& Groth, M. (2014). Developing a mentally healthy workplace: A review of the literature. A report for the National Mental Health Commission and the Mentally Healthy Workplace Alliance.Sydney: School of Psychiatry,University of New South Wales; Black Dog Institute \& Australian School of Business, University of New South Wales.

Koopman, C., Pelletier, K. R., Murray, J. F., Sharda, C. E., Berger, M. L., Turpin, R. S., ...\& Bendel, T. (2002). Stanford presenteeism scale: health status and employee productivity. Journalof Occupational and Environmental Medicine, 44(1), 14-20.

Linley, P.A., \& Joseph, S. (2004). Positive Psychology in Practice. New Jersey: John Wiley \& Sons, Inc.

Little, K., Henderson, C., Brohan, E., \& Thornicroft, G. (2011).Employers' attitudes to people with mental health problems in the workplace in Britain :changes between 2006 and 2009. Epidemiology and psychiatric sciences, 20 (1), 7381.

McCullough, M. E., Emmons, R.A., \& Tsang, J.A (2002). The Grateful Disposition: A Conceptual and Empirical Topography. Journal of Personality and Social Psychology, 82(1), 112

Pramita,

Ecka:

majalah kartin.

https://majalahkartini.co.id/outhor/ecka/page/129. Di Akses pada tanggal 17 September 2018

World Health Organization. (2012). Mental Health: a state of well-being. Diunduh dari WorldHealth Organization: http://www.who.int. Di Akses pada tanggal 30 September 2018 